\title{
ПРОБЛЕМЫ ИСТОРИОГРАФИИ
}

\section{А.А. Мицук \\ «НА ВСЕ ЕСТЬ СВОИ СПЕЦИАЛИСТЫ»: ЭКСПЕРТНАЯ ОЦЕНКА СТАРООБРЯДЧЕСТВА ВТОРОЙ ПОЛОВИНЫ ХІХ в. В ТРУДАХ ПРОФЕССОРА И.Ф. НИЛЬСКОГО}

\begin{abstract}
Статья посвящена особенностям развития нового направления церковно-исторической науки в Санкт-Петербургской духовной академии второй половины XIX столетия - «расколосектанству». На материалах биографии и основных научных работ профессора И.Ф. Нильского выявлен процесс становления православного историка в качестве эксперта по церковному расколу, несогласного с резко негативной оценкой господствующей церкви оппозиционных религиозных течений, в том числе староверия. На примере корпуса рецензий И.Ф. Нильского установлено, что на начальном этапе формирования новой научной дисциплины научная критика способствовала повышению качества публикаций по теме и стала одним из условий формирования экспертного сообщества, специализирующегося на исследовании церковного раскола.

Ключевые слова: И.Ф. Нильский; старообрядчество; церковная историческая наука; научная экспертиза в религиоведении.
\end{abstract}

Развитие церковно-исторической науки в духовных академиях второй половины XIX в. невозможно представить без рассмотрения появившейся в это время новой учебной дисциплины - «расколосектанства». Именно в рамках богословского образования все более утверждалась идея о специальном изучении старообрядчества, которое имело бы не только теоретикометодологическое, но и прикладное значение. Желаемый результат введения науки, постигающей церковный раскол во всем его многообразии, виделся церковно- и священнослужителям в сглаживании негативных последствий, которые накопились в течение двух веков после проведения патриархом Никоном реформ в богослужении [1. С. 6].

Процесс преобразования духовных академий сегодня вновь актуализировал вопрос о включении в учебные планы курса расколоведения как обязательного при подготовке высших церковных кадров. В связи с этим важно обратить внимание на ранее приобретенный опыт, в частности на становление и расцвет данной богословской отрасли науки в дореволюционной России.

Одним из возможных подходов к рассмотрению формирования истории и обличения церковного раскола - неотъемлемой научной дисциплины в высшей и средней духовной школе Российской империи - является реконструкция исторической биографии, которая, по определению известного историка Л.П. Репиной, может выступать не только как цель исследования, но и как «сама история, показанная через личность» [2. С. 288]. Представляется необходимым рассмотреть жизнь и творчество профессора Санкт-Петербургской духовной академии Ивана Федоровича Нильского (1831-1894), занимавшего кафедру истории и обличения русского раскола почти с самого основания этой структуры вплоть до своей кончины.
Востребованность научного наследия И.Ф. Нильского в настоящее время подтверждают работы Е.В. Головань [3], Н.С. Гурьянова [4], А.П. Веселова [5], К.А. Кузоро [6] и др. Отдельно стоит выделить биобиблиографическую статью Д. Залетова, в которой исследователь приходит к выводу, что труды церковного историка «...несомненно, ждут своего изучения и анализа, тем более что вопрос происхождения и развития старообрядчества, а также диалог со староверами актуален и в наши дни» [7]. Соответственно, целью данной статьи является составление научной биографии профессора И.Ф. Нильского с последующим разбором его основных работ.

И.Ф. Нильский родился в 1831 г. в бедной семье сельского диакона псковской епархии. Получив первоначальное домашнее образование, он проходит классический путь детей священнослужителей - духовное училище, затем духовная семинария. Обучаясь в псковской семинарии, он обрел особое расположение епископа рижского Платона (позднее митрополит Киевский и Галицкий). В частности, своим авторитетом епископ спас его от исключения за нарушение правил внутреннего распорядка [8. С. 515-516]. Успешно окончив семинарию в 1853 г., И.Ф. Нильский как лучший студент был отправлен за казенный счет для дальнейшего получения богословского образования в Санкт-Петер-бургскую духовную академию [9. С. 189-190].

Важно отметить, что в 1855-1856 учебном году происходят существенные изменения в преподавании. Например, в число изучаемых студентами учебных предметов включается учение о русском расколе. Более того, по распоряжению митрополита Григория (Постникова) с 1857 г. этот предмет становится самостоятельной дисциплиной и ведется одним преподавателем, а не несколькими, как было ранее, что должно было 
повысить качество преподавания [10. С. 28]. В этом же году на открытую кафедру был отправлен инспектор Смоленской семинарии архимандрит Викторин Любимов. Однако еще до его назначения с разрешения митрополита Григория (Постникова) и тогдашнего ректора Санкт-Петербургской духовной академии епископа Винницкого Макария (Булгакова) чтение лекций по этому предмету было поручено только что окончившему академический курс И.Ф. Нильскому. Для этой ситуации нашлось «соломоново решение»: В. Любимов был переведен на вакантную должность инспектора академии, а И.Ф. Нильский с 11 ноября 1857 г. определен преподавателем кафедры и после шести лет работы получил звание экстраординарного профессора [8. С. $516 ; 10$. С. 45].

Чем же заслужил И.Ф. Нильский такую благосклонность со стороны высших церковных лиц? Видимо, главная причина столь уважительного отношения к его персоне заключалась в написании магистерского сочинения «Об антихристе против раскольников» (1857) [11], которое стало первым полемическим произведением по данному вопросу, высоко оцененным в церковном научном сообществе. Это подтверждает ее публикация в 1859 г. и отзывы рецензентов: «...полнота в исследовании предмета, добросовестный и терпеливый труд в подборе мельчайших частей раскольнического учения, умение удачно воспользоваться ими как для изучения раскольнического учения об антихристе, так и для опровержения его, выбирать из них все нужное для целей книги - вот главные достоинства теоретико-полемической части сочинения» [7].

На следующем этапе изучения старообрядчества И.Ф. Нильский посчитал необходимым рассмотреть «интимные стороны раскольнической жизни, ознакомиться с внутренними движениями в расколе, вывести на свет раскольническую доктрину в ее историческом развитии» [12. T. 1. С. 12], вследствие чего объектом нового исследования становился брак и семья старообрядцев. Стоит заметить, что на выбор темы повлияли проходившие в то время дискуссии о гражданском браке. Итогом ее научного осмысления стала диссертация на степень доктора богословия И.Ф. Нильского «Семейная жизнь в русском расколе» (1869), изданная в 2 томах и охватывающая период от начала церковного раскола до конца царствования императора Николая I $[13,14]$.

Получение высшей ученой степени в системе духовного образования в дальнейшем позволило И.Ф. Нильскому получить звание ординарного профессора академии [12. Т. 1. С. 14]. По регламенту утвержденного Устава духовных академий от 1869 г. степень доктора богословия присуждалась только после обязательной публичной защиты диссертации [15. С. $145-$ 146]. Именно И.Ф. Нильский становится первым преподавателем церковно-исторического отделения, удостоенным степени доктора по результатам защиты своего сочинения в 1870 г. перед многочисленными слушателями [10. С. 121-122].
В дальнейшем направление научной деятельности И.Ф. Нильского значительно изменилось. Им было издано множество статей исторического, библиографического и в основном критического характера в различных журналах: «Христианское чтение», «Церковный вестник», «Странник» и др. [7]. Однако его ученик, известный к тому времени профессор Казанской духовной академии Н.И. Ивановский, отрицательно оценивает работы, написанные им после «Семейной жизни в русском расколе»: «К сожалению, должно сказать, что и вообще интерес [И.Ф. Нильского] к разработке внутренней исторической жизни раскола как-то потерялся. Попадались и попадаются, конечно, в периодических изданиях небольшие отрывочные статейки, но они проходили бесследно и на общее направление исторической науки о расколе влияния не имели» [12. Т. 1. С. 15].

Действительно, И.Ф. Нильский в дальнейшем не публиковал больших научных трудов по истории староверия, но и занижать его роль в науке после 60-70-х гг. XIX столетия не следует. Причина, по которой И.Ф. Нильский переориентировался на написание критических заметок, связана с появлением большого количества работ по старообрядчеству светских и церковных лиц, нередко допускающих ошибки и неточности разного характера: исторические, логические или лингвистические. Такие труды, по его мнению, могли подрывать авторитет официальной церкви и давать староверам аргументы для полемики с православными миссионерами. Профессор И.Ф. Нильский посчитал своим долгом в новых сочинениях о церковном расколе не скрывать, а прямо указывать на допущенные ошибки, тем самым пытаясь показать старообрядцам, что эти недостатки относятся к отдельным исследователям и не должны переноситься на православную церковь в целом [16. С. 313-314].

Основополагающим методом И.Ф. Нильского для выявления некачественных работ по истории староверия становится критика, цель которой «состоит в том, чтобы, показав недостатки рассматриваемого сочинения, установить правильный взгляд на предмет его и наметить по возможности те его стороны, которые почему-либо требуют преимущественного раскрытия и уяснения» [Там же. С. 317-318]. Примечателен тот факт, что в написании критических заметок профессор добился ощутимых высот: например, за рецензию на сочинение профессора Московской академии Н.И. Субботина, написанную по поручению Академии наук в 1875 г., он был удостоен золотой Уваровской медали [10. С. 152].

Преподавательская нагрузка И.Ф. Нильского на кафедре истории и обличения русского раскола в течение 37 лет состояла в чтении лекций по «расколосектанству» студентам старших курсов. Аудитория профессора, по утверждению его учеников, всегда была полна слушателей [12. Т. 1. С. 6-7], а сами лекции «отличались богатством новых сообщаемых сведений, простотой и живостью изложения» [17. С. 515]. Отличитель- 
ная черта изложения материала И.Ф. Нильским - приведение многочисленных примеров в ходе занятия [7]. Такой способ чтения лекций позволял, во-первых, лучше раскрывать теоретические основы предмета и, вовторых, включать студентов в обсуждение спорных и неоднозначных случаев из истории церковного раскола.

В библиотеке Санкт-Петербургской духовной академии до сих пор хранится немало студенческих конспектов лекций И.Ф. Нильского разных лет, отпечатанных литографическим способом [7]. Скорее всего, желание слушателей в таком массовом распространении материала обусловлено тем, что преподаваемый предмет во всех духовных академиях еще не был окончательно сформирован, а получение положительной отметки предполагало знание и понимание фактов, постоянно корректируемых и дополняемых профессором.

В отчете ревизии Санкт-Петербургской духовной академии 1875 г. уже в сане архиепископа Виленского и Литовского Макарий (Булгаков) оставляет лестный отзыв о профессионализме И.Ф. Нильского, но при этом указывает, что, следуя учебному плану, он едва успевает прочесть в лекционном формате только одну часть своей дисциплины - историю церковного раскола [18. С. 378].

Однако нехватка времени при изложении студентам полного курса была проблемой не только И.Ф. Нильского, но и всей преподавательской корпорации академии. В значительной степени, как показала ревизия, возникшая трудность связана с уже не соответствующим реалиям распределением часовой нагрузки между обязательными и специальными предметами по Уставу духовных академий 1869 г. К примеру, наставники церковно-исторического отделения, к которому был прикреплен И.Ф. Нильский, требовали исключения метафизики из числа общеобязательных курсов из-за «перегруженности» студентов [Там же. С. 398].

Помимо учебной и научно-исследовательской нагрузки И.Ф. Нильский занимал служебные посты в стенах «alma mater». Так, имея ученую степень магистра, он несколько лет (1858-1860) трудился в качестве помощника инспектора Санкт-Петербургской духовной академии, а с сентября 1878 г. в течение семи лет был полноправным ее инспектором [8. С. 516]. В воспоминаниях его ученик - профессор А.А. Бронзов, отмечая строгость и принципиальность И.Ф. Нильского, пишет: «Если кому-либо нужно было сходить в лекционные часы... в город, то такой обычно уходил по Обводному каналу, не решаясь пройти мимо окон инспекторской квартиры из боязни попасть на глаза бдительному И.Ф. Нильскому или “в объятия” самому ректору...» [7]. К тому же занимаемая должность инспектора автоматически вводила И.Ф. Нильского в состав Правления Санкт-Петербургской духовной академии [10. С. 114], занимавшегося преимущественно хозяйственными вопросами: составлением смет, управлением собственностью, поддержанием чистоты в зданиях и т.д. [18. С. 391].

По указу Святейшего Синода от 31 июля 1869 г. И.Ф. Нильский с М.О. Кояловичем были назначены в
Совет академии, где они отвечали за воспитательную и учебную функции студентов церковно-исторического отделения [10. С. 134]. Кроме того, члены Совета академии на заседаниях, которые проходили еженедельно, а иногда и дважды в неделю, обязывались решать важные вопросы жизнеобеспечения и развития академии [18. C. 391].

Высшее начальство Санкт-Петербургской академии осознавало, что главной движущей силой образовательного и научного потенциала являются ее учащиеся, поэтому в 1877 г. учредило Общество вспомоществования недостаточным студентам, оказывающее помощь студентам деньгами, вещами, частичной оплатой аренды жилья и т.д. Бюджет организации в основном состоял из пожертвований академических периодических изданий и преподавателей академии, которых нередко поощряли за благотворительность. И.Ф. Нильский оказался в числе тех, кто по распоряжению Св. Синода в 1881 г. был награжден за свою благотворительную деятельность грамотой [10. С. 183-184], а через два года на основании 9-го параграфа Устава 1869 г. «за особые труды по делам общества» был избран в его почетные члены [19. С. 12].

Кроме того, И.Ф. Нильский участвовал в работе различных общественно-религиозных объединений, например отдела Общества любителей духовного просвещения, открытого в столице в 1872 г. Предполагалось, что образованная организация, в которую входили священнослужители, светские лица и преподаватели академии, через лекционную и издательскую деятельность сможет вызвать интерес в православном обществе к религиозным вопросам [10. С. 164-165]. И.Ф. Нильский не раз выступал с докладами, посвященными истокам разногласий между старообрядцами и православной церковью в России. Так, на заседаниях Общества в течение января-марта 1872 года один из защитников старообрядцев Т.И. Филиппов сделал три сообщения о единоверии и его проблемах. Ответной реакцией на них, кроме коротких критических замечаний профессоров И.А. Чистовича, И.В. Чельцова и протоиерея И.В. Васильева, были «пространные и веские» возражения И.Ф. Нильского. Дискуссии между Т.И. Филлиповым и И.Ф. Нильским о трудностях единоверия в прошлом и современности возобновились в отделе общества через два года - в феврале и марте 1874 года [7].

В связи с большой учебной и административной нагрузкой у И.Ф. Нильского появляются проблемы со здоровьем. В июле 1885 г. он по собственному прошению освобождается от исполнения обязанностей инспектора и члена Правления академии [10. С. 200] и посвящает освободившееся время преподаванию истории и обличения русского раскола. Тем не менее его состояние продолжало ухудшаться, и несколько месяцев в 1893 г. он пролежал с тяжелой болезнью - пороком сердца. Восстановив силы, И.Ф. Нильский возвращается в академию и принимает летние экзамены у студентов - уже последних в его жизни [8. С. 515-516]. 
Причина, по которой он оттягивал отставку, несмотря на ухудшающееся самочувствие, заключалась в размере пенсионного обеспечения преподавателей духовных академий тех лет. Для профессора И.Ф. Нильского, «завоевавшего трехтысячное жалованье», это означало переход «на скудную пенсию в какую-нибудь тысячу рублей, следовательно, из относительного довольства к бедности и недостаткам» [8. С. 517]. Нужда в материальном обеспечении заставляла его трудиться в духовной академии до конца жизни.

Рассмотрим основные труды И.Ф. Нильского в хронологической последовательности, чтобы показать развитие и динамику его представлений, связанных с изучением старообрядчества.

Еще в студенческие годы И.Ф. Нильский пишет свое первое крупное сочинение «Об антихристе против раскольников» (1859) [20], которое было посвящено эсхатологическому сознанию староверов. Во введении к этой работе автор излагает суть и историю формирования старообрядческого учения об антихристе. Затем И.Ф. Нильский выделяет составные части этого учения - «ложные мнения», которые в дальнейшем опровергает одно за другим. Свою задачу автор видит в выработке стратегии, которая поможет вести полемику со старообрядцами по вопросу о сущности антихриста [6. С. 148-149]. По его замыслу, следовало сначала опровергнуть основные характеристики антихриста («о лице антихриста; об образе рождения матери, от которой он родится; о продолжении царства антихриста на земле»), а потом «прямые и положительные доказательства раскольников, которые они приводят в подтверждение той главной мысли, будто антихрист уже царствует в мире» [21. С. 116].

Особое значение И.Ф. Нильский придавал источникам, на которых строил свои рассуждения о несостоятельности старообрядческого учения об антихристе. Понимая, что в полемике со староверами следует использовать определенную литературу, автор предлагает привлекать следующие источники: а) старопечатные книги и рукописи XI-XVI вв., созданные до реформы патриарха Никона и содержащие старославянские переводы свидетельств св. отцов; б) особо уважаемые староверами издания - Кириллову книгу, Книгу о вере, Большой и Малый катехизис и др. [20. С. 29]. Проявляя внимательное отношение к историческим источникам и избегая двусмысленных интерпретаций, И.Ф. Нильский изучает тексты, трактуя которые староверы приходили к оригинальным выводам. Историк приходит к заключению, что рассматриваемое учение старообрядцев содержит в себе множество противоречивых суждений и аргументов, следовательно, не является истинным [6. С. 148-149].

В сочинении «Об антихристе против раскольников» важное место И.Ф. Нильский отводит обличению трактовок старообрядцев об антихристе, а не научному осмыслению этого учения, как это было сделано, например, в работе Н.С. Гурьяновой [22]. Однако из-за отсутствия трудов православных ученых по этой теме до середины XIX в., рассматриваемая студенческая диссертация после публикации получила признание и послужила отправной точкой в становлении И.Ф. Нильского как эксперта по церковному расколу.

В совершенно другой манере написана небольшая по объему брошюра И.Ф. Нильского «Взгляд раскольников на некоторые наши обычаи и порядки жизни церковной, государственной, общественной и домашней» (1863) [23], где он отмечает отсутствие обсуждения в современной ему литературе вопросов, касающихся взглядов староверов «на разные житейские предметы» и ставит целью своего сочинения показать «воззрения раскольников на разного рода существующие в православном обществе обычаи и порядки жизни - без отношения к тому, что во взгляде раскольников есть справедливого и что должно быть признано плодом их неразвитого ума или запуганного воображения». Историк рассматривает взгляды старообрядцев на такие элементы общественной и политической жизни, как медицина, светская литература, современнаяю мода, устройство судов, полиция, паспорта, проведение народной переписи. В этом произведении автор подолгу не задерживается на каждом из предметов и не изучает все аспекты того или иного воззрения. Его сочинение, носящее просветительский характер, скорее всего, предназначалось для православных миссионеров и светских лиц, которые по роду деятельности взаимодействуют со староверами. Не обличить старообрядцев, а в доступной форме рассказать о них - это и является центральной идеей данного сочинения И.Ф. Нильского [6. С. 149].

И.Ф. Нильский в последующее время переориентировался на рецензирование научных работ. Наиболее значимые как для научной общественности, так и для последующего выбора ученым направления в изучении старообрядчества в этом ключе написаны «Об издании Стоглава в Лондоне» (1861) [24] и «Несколько слов о русском расколе» (1864) [25].

Стоглав - многоплановый исторический памятник права, утвержденный на церковно-земском соборе в Москве в 1551 г. Многие главы этого документа посвящены регулированию брачно-семейных отношений жителей Русского государства в XVI в. Впервые печатный Стоглав был опубликован в 1860 г. «Вольной русской типографией Тюбнера» в Лондоне, предположительно, старовером, имя которого скрыто инициалами - «И.А.». Церковный историк Д. Стефанович выдвинул гипотезу, что отсутствие публикаций Стоглава в России связано не с церковной цезурой, а с тем, что никто не брался за это трудное дело [26. Т. 2. С. 250]. Совершенно противоположную позицию занимал И.Ф. Нильский, утверждавший, что причина позднего издания Стоглава состоит в том, «что этого требовали условные обстоятельства, именно - полемика, завязавшаяся между православными и раскольниками, которые ссылаются на Стоглав» [24. С. 8]. Соответственно, 
чтобы не дать старообрядческим начетчикам привлечь на свою сторону еще большее количество верующих, нужно ограничить распространение Стоглава как авторитетного источника в среде староверов.

В дальнейшем И.Ф. Нильский негативно оценивает лондонское издание Стоглава, указывая за наличие грубых ошибок в самом тексте, а в заключении пишет, что «...в тысячу раз лучше иметь у себя рукописный Стоглав, или даже вовсе не иметь, чем иметь печатный такой, в котором не только изменена «роскошная неграмотность XVI в.», вещь немаловажная для любителей старины, но испорчен по местам самый текст, извращен самый смысл памятника». Выявленные им недостатки, скорее всего, объяснялись стремлением издателей «перевести» Стоглав, сделать его современным [26. Т. 2. С. 250].

Другая рецензия И.Ф. Нильского - «Несколько слов о русском расколе» - вызвала критику основоположника демократического направления в изучении старообрядчества А.П. Щапова, который представил староверие как выражение социальных противоречий эпохи: народного протеста против многочисленных сборов и податей, закрепощения крестьянства. В сочинении «Земство и раскол» (1862) А.П. Щапов, рассматривая земство в славянофильском духе как народную массу, противопоставленную государству и высшим сословиям, видит в староверии «могучую, страшную общинную оппозицию податного земства» [6. С. 133-134].

Опровергая воззрения А.П. Щапова, И.Ф. Нильский доказывает, что старообрядчество состояло не только из податного земства. Это религиозное движение привлекало и объединяло лиц всех сословий и званий, включая самых высших: «последователей и в роскошных палатах бояр и князей, и в скромных хижинах протопопов и попов, и в тихих кельях архиереев, архимандритов, иеромонахов» [25. С. 7]. Помимо указаний на логику изложения и идей рецензируемого сочинения И.Ф. Нильский замечает за автором отсутствие ссылок на источники, из которых он заимствует какие-либо сведения для аргументации позиции [Там же. С. 46], что, конечно, дискредитировало А.П. Щапова в профессиональном научном сообществе.

Церковный раскол, по мнению И.Ф. Нильского, явление только религиозного характера, а не протест податного земства против всего государственного строя. Профессор определяет свое отношение к старообрядчеству как восстание против православной церкви и отделение от нее верующих из-за некоторых обрядовых различий [27. С. 804]. Следовательно, чтобы полемика православных против старообрядцев достигала успеха, необходимо исследовать обряды и таинства, которые изменялись под влиянием конкретных причин. Именно поэтому И.Ф. Нильский концентрирует внимание на изучении старообрядческого учения о семье и браке.

С середины XIX в. исследования брачных отношений старообрядцев проходят в русле юридического под- хода, и основным источником становятся документы, имеющие силу закона: правительственные законодательные акты, регулирующие семейно-брачные взаимоотношения староверов; полемико-догматические произведения о браке лидеров старообрядческих общин, которые имели нормативное значение для многих «раскольников». Становление данного направления, во-первых, обусловлено волной общего интереса к староверию и разносторонним характером научных сочинений, направленных на систематизацию всей накопившейся к тому времени информации о церковном расколе. Во-вторых, оно было связано с реформированием судебной системы в эпоху правления Александра II. В частности, долгие дискуссии проходили по проблеме определения и ограничения компетенций духовных судов, особенно в регулировании брачного права.

Именно на пересечении двух установок: общего интереса к староверию и поиска адекватных путей преобразования брачного права, находится исследование И.Ф. Нильского «Семейная жизнь в русском расколе» [28. C. 52].

Было ли совершение таинства венчания при отсутствии священства самым спорным вопросом для беспоповских старообрядческих толков и согласий? И.Ф. Нильский в начале своего сочинения указывает цель «ознакомить читающий мир с этим вопросом в его постепенном историческом ходе и развитии». Поставленная автором цель носила научный характер: ученый не осуждает учение беспоповцев, а трактует его как имевшее реальное значение и место в прошлом. Несмотря на это, критической оценке подвергаются поступки лидеров и отдельных представителей старообрядческого мира. В числе многочисленных источников И.Ф. Нильский нередко обращается к сочинениям беспоповцев, к которым он относится именно как к историческому источнику, содержащему важные сведения об изменениях в учении староверов о браке [21. С. 117].

На наш взгляд, следует определить возможную схему разбора учения старообрядцев о браке в «Семейной жизни в русском расколе», где его отдельные положения рассматриваются И.Ф. Нильским в произвольном порядке:

- описание событий или процессов, которые влияли на восприятие таинства брака старообрядцев разных толков и согласий. Чаще всего в сочинении приводится появление новых трактовок и суждений лидеров староверов по вопросам брака (И. Алексеев, И.А. Ковылин, В. Емельянов и др.);

- реакция светской власти на появление новых форм брачных взаимоотношений в старообрядческой среде (всеобщее девство, блуд, «новоженство»). Политика государства в отношении старообрядцев показана в хронологическом порядке от современника церковного раскола - царя Алексея Михайловича - до конца царствования императора Николая I;

- меры церковной власти по разоблачению учения староверов о браке и восстановлению авторитета таин- 
ства венчания, совершаемого по канонам православной церкви.

В своей докторской диссертации И.Ф. Нильский опровергает представления А.П. Щапова о браках старообрядцев, высказанные последним в работе «Русский раскол старообрядства» (1859). А.П. Щапов утверждал, что староверы, установив безбрачие, пытались привлечь на свою сторону простых людей, «пренебрегавших нравственными постановлениями церкви» и имевших «привычку к грубой, ничем не сдерживаемой свободе жизни». И.Ф. Нильский рассматривал учение беспоповцев о безбрачии как имевшее серьезные догматические и обрядовые основания. С уважением к старообрядцам он пишет, что «как ни своеобразны были раскольники в своих понятиях о добродетели, все же они не были настолько грубы и дики, чтобы безнравственность стали считать нравственностью» [6. С. 152].

«Семейная жизнь в русском расколе» стала последней крупной работой И.Ф. Нильского. Возможно, одной из причин успеха и постепенного признания идей историка, а его самого в качестве эксперта в области брачных отношений староверов, являются мировоззренческие установки в отношении церковно-исторической науки, где И.Ф. Нильский реализовывал свои научные амбиции.

В целом он признавал существование закономерностей исторического развития общества, но, как ни парадоксально, с зависимостью от человеческого фактора, из-за чего ход исторических событий является «вовсе не прямолинейным, напротив, он идет прихотливыми извивами, то стремясь вперед, то уклоняясь в сторону, то возвращаясь назад, то отклоняясь вовсе от цели, или останавливаясь на известной ступени». Соответственно, И.Ф. Нильский рассматривает историю как результат «сталкивающихся и переплетающихся случайностей», рожденных действиями отдельных личностей под давлением внешних обстоятельств. На примере церковного раскола XVII в. историк утверждает, что причины раскола следует искать не только в религиозной жизни русского народа, но также в тех случайных частностях, которыми была полна Россия в период патриаршества Никона [29. С. 138-139].

Анализ научных трудов И.Ф. Нильского приводит к следующим выводам. Во-первых, вектор развития исторической науки в Санкт-Петербургской духовной академии отразил научный интерес самого И.Ф. Нильского к старообрядческим учениям об антихристе и браке. По замыслу ученого, их изучение не только должно было помочь успешному ведению полемики православных миссионеров против староверов, но также имело целью выработать стратегию взаимодействий государства, русской православной церкви и общества со староверами.

Во-вторых, оставленный И.Ф. Нильским огромный корпус рецензий на научные работы, посвященные истории старообрядчества, как светских исследователей, так и коллег по «цеху», свидетельствует о том, что, несмотря на позднее появление новой научной отрасли в богословском образовании - «расколосектанства», именно эта область исторического познания быстро развивается и становится востребованной. Совокупный анализ издаваемых полемических и исторических сочинений и критических отзывов на них позволяет увидеть, какие гипотезы и теории утверждались в науке, а какие идеи были вовсе отброшены из-за слабости аргументации.

Биография И.Ф. Нильского свидетельствует о становлении качественно нового специалиста, который должен был стать по возможности независимым от отношения господствующей церкви к оппозиционным конфессиям и верованиям и уметь отказываться от убежденности в культурной несостоятельности старообрядчества. На протяжении всей своей жизни он пытался понять мотивы и причины, заставляющие людей оставаться в староверии, и это отразилось на содержательной стороне его работ, которые различаются по манере написания и структуре изложения. Однако главной заслугой И.Ф. Нильского в формировании сообщества экспертов, иными словами - корпорации ученых-расколоведов, стала научная коммуникация с другими представителями церковных историков, отраженная корпусом его критических статей и рецензий.

\section{ЛИТЕРАТУРА}

1. Слесарев А.В. Расколоведение. Введение в понятийный аппарат. М. : Новоспасский мужской монастырь, 2012.207 с.

2. Репина Л. П. Историческая наука на рубеже XX-XXI в.: социальные теории и историографическая практика. М. : Кругъ, 2011.560 с.

3. Головань Е.В. Раскол в исследованиях второй половины XIX в. (по каталогам библиотеки костромского общественного собрания, (18991906)) // Современные проблемы науки и образования. 2015. № 1-1. URL: https://science-education.ru/ru/article/view?id=18441 (дата обращения: 03.11.2017).

4. Гурьянова Н.С. О восприятии старообрядцами эсхатологических построений предшественника // Гуманитарные науки в Сибири. 2011 . № 3. C. 58-61.

5. Веселова А.П. Семья в старообрядческой культуре: опыт исторического исследования : дис. ... канд. ист. наук. Томск, 2007.229 с.

6. Кузоро К.А. Церковная историография старообрядчества: возникновение и эволюция (вторая половина XVII - начало XX вв.) / под ред. Е.Е. Дутчак. Томск : Изд-во Том. ун-та, 2011. 182 с.

7. Залетов Д. Заслуженный профессор Санкт-Петербургской духовной академии Иван Федорович Нильский (к 110-летию со дня кончины) // Церковный вестник. 2004. № 10-11. URL: http://krotov.info/spravki/1 history bio/19 1890/1831 Nilsky.htm (дата обращения: 06.11.2017).

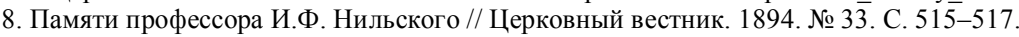

9. Известия и заметки // Странник. 1894. № 9. С. 189-191.

10. Чистович И.А. Санкт-Петербургская духовная академия за последние 30 лет (1858-1888 гг.). СПб. : Тип. Св. Синода, 1889. II, $232,164,2$ с.

11. Нильский И.Ф. Об антихристе против раскольников. Сочинение бакалавра Санкт-Петербургской духовной академии. СПб. : Тип. Николая Тихменева, 32, 1859. XXXVI, $511 \mathrm{c}$

12. Ивановский Н.И. Памяти профессора Ив.Ф. Нильского // Собрание сочинений профессора Казанской духовной академии Николая Ивановского : сб. ст. / под ред. А. Волкова. Казань : Тип.-лит. Императ. ун-та, 1898. Т. 1. 490 с. 
13. Нильский И.Ф. Семейная жизнь в русском расколе. Исторический очерк раскольнического учения о браке. От начала раскола до царствования императора Николая I. СПб. : Тип. департамента уделов, 1869. Вып. 1. 406, IV с.

14. Нильский И.Ф. Семейная жизнь в русском расколе. Исторический очерк раскольнического учения о браке. Царствование императора Николая I. СПб. : Тип. департамента уделов, 1869. Вып. 2. 256, IV c.

15. Сухова Н.Ю. «Идея академии» в подготовке и проведении духовно-учебных реформ XIX - начала XX вв. // Вестник Екатеринбургской духовной семинарии. 2013. Вып. 2 (6). С. 138-153.

16. Нильский И.Ф. Объяснение // Христианское чтение. 1865. Ч. 2. С. 280-326.

17. Слово, произнесенное протоиереем П.Ф. Николаевским во время заупокойной литургии, отслуженной пред погребением проф. И.Ф. Нильского // Церковный вестник. 1894. № 33. С. 514-515.

18. Карпук Д.А. «Я признаю состояние Санкт-Петербургской духовной академии вообще очень удовлетворительным во всех отношениях» : отчет архиепископа Макария (Булгакова) о ревизии Санкт-Петербургской духовной академии в 1875 г. / вступ. статья, публ. и примеч. Д.А. Карпука // Христианское чтение. 2016. № 4. С. 365-410.

19. Отчет распорядительного комитета общества вспомоществования недостаточным студентам Санкт-Петербургской духовной академии за седьмой 1883-1884 год // Церковный вестник. 1884. № 19. С. 12.

20. Нильский И.Ф. Об антихристе против раскольников (в общепонятном изложении) : в 2 ч. СПб. : Изд. книгопродавца И. Перевозникова, $1898.382,14 \mathrm{c}$.

21. Кузоро К.А. Направления исследования старообрядчества в синодальной (церковной) историографии последней трети ХІХ - начала ХХ в. // Вестник Томского государственного университета. 2009. № 320. С. 115-118.

22. Гурьянова Н.С. Крестьянский антимонархический протест в старообрядческой эсхатологической литературе периода позднего феодализма. Новосибирск : Наука, 1988. 188 с.

23. Нильский И.Ф. Взгляд раскольников на некоторые наши обычаи и порядки жизни церковной, государственной, общественной и домашней. СПб. : Тип. департамента уделов, 1863.72 с.

24. Путешествующий. Об издании Стоглава в Лондоне (письмо из-за границы). СПб. : Тип. департамента уделов, 1861.17 с.

25. Нильский И.Ф. Несколько слов о русском расколе. По поводу брошюры: «Земство и раскол» А. Щапова 1862 г. СПб. : в тип. департамента уделов, 1864. $160 \mathrm{c}$.

26. Российское законодательство X-XX веков: Законодательство периода образования и укрепления Русского централизованного государства : в 9 т. / отв. ред. А.Д. Горский ; под общ. ред. О.И. Чистякова. М. : Юрид. лит., 1985. Т. 2. 520 с.

27. По поводу тридцатилетия ученой деятельности Ивана Федоровича Нильского // Церковный вестник. 1887. № 46. С. $803-804$.

28. Веселова А.П. Исследовательские практики при изучении старообрядческой семьи: историографический обзор // Вестник Томского государственного университета. 2007. № 300-3. С. 52-54.

29. Нильский И.Ф. Несколько слов о происхождении раскола // Христианское чтение. 1861. Ч. 1. С. $89-154$.

Mitsuk Alexey A. National Research Tomsk State University (Tomsk, Russian Federation). E-mail: rixalos@mail.ru

«EVERYTHING HAS ITS EXPERTS»: EXPERT REVIEW OF OLD-BELIEVERS IN THE SECOND HALF OF THE XIX CENTURY IN THE TREATISES OF PROFESSOR I.F. NILSKY.

Keywords: I.F. Nilsky; old-believer`s; church historical science; scientific expertise in religious studies.

In the second half of the XIX century, the highest spiritual institutions of Moscow, St. Petersburg, Kazan and Kiev went through significant changes in the research and educational spheres, in consequence a special branch of church history - "schismaticism" emerged. This branch was aimed to study the life and activities of the old-believers from the beginning of the church schism up to the Emperor Nicholas I modern orders on the civil and religious rights of the opposition confession. After the departments on the history and exposure of the church / Russian schism were opened at the theological academies, most of the church author's writings were focused on identifying the reasons and factors of the different understanding of church rites by official orthodoxy and old-belief. One of these writers was the professor of St. Petersburg Theological Academy I.F. Nilsky. Corpus of his works makes changes in the scientific understanding of church schism scientists the second half of the XIX century trackable, and in correlation with the biography of I.F. Nilsky it creates an important source for researching the processes of developing a scientific study of this topic.

Using the methodology of a scientific biography compilation, which is aimed at establishing the historical context of the creation of scientific texts, the author comes to the following conclusions. Firstly, the scientific interests of I.F. Nilsky, which set the vector for the development of historical science in the St. Petersburg Theological Academy, focused on the examination of the old-believers teachings on antichrist and marriage. According to the scientist's suggestion, their development could help special missionaries in disputes with the old-believers, and in addition, contributed to the formation of a strategy for interaction between the old-believers and state apparatus, church authorities and the different layers of the population of the Russian Empire.

Secondly, I.F. Nilsky's numerous reviews on the scientific works of secular and religious researchers of the history of the old-believers, show that the new church-historical discipline - "schismaticism", separated from the accusatory theology and became popular and socially relevant area of historical knowledge. The study of historical and polemic publications of that time and its critical reviews, gives an opportunity to track which hypotheses and theories were adopted in the scientific community, and which ideas failed because of insufficient reasoning. Accordingly, the scientific heritage of Professor I.F. Nilsky becomes a demonstrative example of the process of forming a qualitatively new specialist - an expert on church schism. His distinctive characteristic is a partial independence from the dominant church's critical attitude to oppositional confessions and beliefs, as well as the ability to abandon the stereotype of the cultural inadequacy of the old-believers. An important contribution of I.F. Nilsky in the formation of the community of experts is scientific communication with other church authors, reflected in the corpus of his critical articles and reviews.

\section{REFERENCES}

1. Slesarev, A.V. (2012) Raskolovedeniye. Vvedeniye v ponyatiynyy apparat [Schismology. Introduction to the conceptual apparatus]. Moscow: Novospasskiy muzhskoy monastyr'.

2. Repina, L.P. (2011) Istoricheskaya nauka na rubezhe XX-XXI v.: sotsial'nyye teorii i istoriograficheskaya praktika [History at the turn of the 21 st centiry: Social theories and historiographical practices]. Moscow: Krug".

3. Golovan, E.V. (2015) The schism in the studies in the second half of the 19th century (according to the catalogs of the Kostroma Social Gathering Library (1899-1906)). Sovremennyye problemy nauki i obrazovaniya - Modern Problems of Science and Education. 1(1). [Online] Available from: https://science-education.ru/ru/article/view?id=18441. (Accessed: 3rd November 2017). (In Russian).

4. Guryanova, N.S. (2011) About the Old Believer's Interpretation of the Eschatological Ideas of Their Predecessor. Gumanitarnyye nauki v Sibiri. 3. pp. 58-61. (In Russian).

5. Veselova, A.P. (2007) Sem'ya v staroobryadcheskoy kul'ture: opyt istoricheskogo issledovaniya [Family in the Old-Believers culture: Experience of historical research]. History Cand. Diss. Tomsk. 
6. Kuzoro, K.A. (2011) Tserkovnaya istoriografiya staroobryadchestva: vozniknoveniye i evolyutsiya (vtoraya polovina XVII - nachalo XX vv.) [Church historiography of the Old-Believers: Emergence and evolution (the second half of the 17th - early 20th centuries)]. Tomsk: Tomsk State University.

7. Zaletov, D. (2004) Zasluzhennyy professor Sankt-Peterburgskoy dukhovnoy akademii Ivan Fedorovich Nil'skiy (k 110-letiyu so dnya konchiny) [Honoured professor of the St. Petersburg Theological Academy Ivan Fedorovich Nilskii (to 110 years since his decease)]. Tserkovnyy vestnik. 1011. [Online] Available from: http://krotov.info/spravki/1_history_bio/19_1890/1831_Nilsky.htm. (Accessed: 6th November 2017).

8. Anon. (1894) Pamyati professora I. F. Nil'skogo [In memory of Professor I.F. Nilsky]. Tserkovnyy vestnik. 33. pp. 515-517.

9. Anon. (1894) Izvestiya i zametki [News and notes]. Strannik. 9. pp. 189-191.

10. Chistovich, I.A. (1889) Sankt-Peterburgskaya dukhovnaya akademiya za posledniye 30 let (1858-1888 gg.) [St. Petersburg Theological Academy for the last 30 years (1858-1888)]. St. Petersburg: Tip. Sv. Sinoda.

11. Nilskiy, I.F. (1859) Ob antikhriste protiv raskol'nikov. Sochineniye bakalavra Sankt-Peterburgskoy dukhovnoy akademii [About the Antichrist against the Schematics. Bachelor's Thesis, St. Petersburg Theological Academy]. St. Petersburg: Tip. Nikolaya Tikhmeneva v Troitsk.

12. Ivanovskiy, N.I. (1898) Sobraniye sochineniy professora Kazanskoy dukhovnoy akademii Nikolaya Ivanovskogo [Collected Works by Professor Nikolai Ivanovsky of the Kazan Theological Academy]. Vol. 1. Kazan: Imperial University.

13. Nilskiy, I.F. (1869a) Semeynaya zhizn'v russkom raskole. Istoricheskiy ocherk raskol'nicheskogo ucheniya o brake. Ot nachala raskola do tsarstvovaniya imperatora Nikolaya I [Family life in the Russian schism. The historical analytical review of the schismatic doctrine of marriage. From the beginning of the church schism until the reign of Emperor Nicholas I]. Issue 1. St. Petersburg: Tip. departamenta udelov.

14. Nilskiy, I.F. (1869b) Semeynaya zhizn'v russkom raskole. Istoricheskiy ocherk raskol'nicheskogo ucheniya o brake. Ot nachala raskola do tsarstvovaniya imperatora Nikolaya I [Family life in the Russian schism. The historical analytical review of the schismatic doctrine of marriage. From the beginning of the church schism until the reign of Emperor Nicholas I]. Issue 2. St. Petersburg: Tip. departamenta udelov.

15. Sukhova, N.Yu. (2013) "Ideya akademii" v podgotovke i provedenii dukhovno-uchebnykh reform XIX - nachala XX vv. ["The idea of Academy" in preparing and conducting spiritual and educational reforms in the 19th - early 20th centuries]. Vestnik Yekaterinburgskoy dukhovnoy seminarii. 2(6). pp. $138-153$.

16. Nilskiy, I.F. (1865) Ob"yasneniye [Explanation]. Khristianskoye chteniye. 2. pp. 280-326.

17. Nikolayevsky, P.F. (1894) Slovo, proiznesennoye protoiyereyem P.F. Nikolayevskim vo vremya zaupokoynoy liturgii, otsluzhennoy pred pogrebeniyem prof. I.F. Nil'skogo [The speech delivered by Protopriest P.F. Nikolaevsky during the funeral service before the burial of Prof. I.F. Nilsky]. Tserkovnyy vestnik. 33. pp. 514-515.

18. Karpuk, D.A. (2016) "I claim that the state of St. Petersburg Theological Academy is very satisfactory in all dimensions". Archbishop Macarius (Bulgakov) on the Review of St. Petersburg Theological Academy in 1875. Khristianskoye chteniye. 4. pp. 365-410. (In Russian).

19. The Society for the Supporting of Poor Students of St. Petersburg Theological Academy. (1884) Otchet rasporyaditel'nogo komiteta obshchestva vspomoshchestvovaniya nedostatochnym studentam Sankt-Peterburgskoy dukhovnoy akademii za sed'moy $1883-1884$ god [The report of the Administrative Committee of the Society for the Supporting of Poor Students of St. Petersburg Theological Academy for 1883-1884]. Tserkovnyy vestnik. 19. pp. 12.

20. Nilskiy, I.F. (1898) Ob antikhriste protiv raskol'nikov (v obshcheponyatnom izlozhenii): $v 2$ ch. [On the Antichrist against the Schematics (in a generally understandable way]. St. Petersburg: I. Perevoznikov.

21. Kuzoro, K.A. (2009) Research trends of the Old Belief in a Synodal (church) historiography of the late of the 19th - early of the 20th centuries. Vestnik Tomskogo gosudarstvennogo universiteta - Tomsk State University Journal. 320. pp. 115-118. (In Russian).

22. Guryanova, N.S. (1988) Krest'yanskiy antimonarkhicheskiy protest v staroobryadcheskoy eskhatologicheskoy literature perioda pozdnego feodalizma [Peasant antimonarchic protest in the Old Believers' eschatological literature of the late feudal period]. Novosibirsk: Nauka.

23. Nilskiy, I.F. (1863) Vzglyad raskol'nikov na nekotoryye nashi obychai i poryadki zhizni tserkovnoy, gosudarstvennoy, obshchestvennoy i domashney [The Old Believers on some of our customs and practices of church, state, public and domestic life]. St. Petersburg: Tip. departamenta udelov.

24. Puteshestvuyushchiy. (1861) Ob izdanii Stoglava v Londone (pis'mo iz-za granitsy) [On the publication of Stoglav in London (A letter from abroad)]. St. Petersburg: Tip. departamenta udelov.

25. Nilskiy, I.F. (1864) Neskol'ko slov o russkom raskole. Po povodu broshyury: "Zemstvo i raskol” A. Shchapova 1862 g. [A few words about the Russian schism. Regarding the brochure "Zemstvo and schism" by A. Shchapov, 1862]. St. Petersburg: V tip. departamenta udelov.

26. Gorskiy, A.D. (ed.) (1985) Rossiyskoye zakonodatel'stvo X-XX vekov: Zakonodatel'stvo perioda obrazovaniya i ukrepleniya Russkogo tsentralizovannogo gosudarstva [Russian legislation of the 10th - 20th centuries. Legislation during period of establishing and strengthening of the Russian centralized state]. Vol. 2. Moscow: Yuridicheskaya literatura.

27. Anon. (1887) Po povodu tridtsatiletiya uchenoy deyatel'nosti Ivana Fedorovicha Nil'skogo [Regarding the thirtieth anniversary of Ivan Fyodorovich Nilsky's academic activities]. Tserkovnyy vestnik. 46. pp. 803-804.

28. Veselova, A.P. (2007) Issledovatel'skiye praktiki pri izuchenii staroobryadcheskoy sem'i: istoriograficheskiy obzor [The research practices related to the Old Believer's family: A historiographical review]. Vestnik Tomskogo gosudarstvennogo universiteta - Tomsk State University Journal. 300(3). pp. 52-54.

29. Nilskiy, I.F. (1861) Neskol'ko slov o proiskhozhdenii raskola [A few words about the origin of the schism]. Khristianskoye chteniye. 1. pp. 89-154. 